\title{
FORGATTYÚS TENGELY FORGÁCSOLÓ MEGMUNKÁLÁSOK KÖZBENI KIEGYENSÚLYOZÁSA
}

\author{
Gazdag Patrik \\ MSc hallgató, Miskolci Egyetem, Gyártástudományi Intézet \\ 3515 Miskolc, Miskolc-Egyetemváros, e-mail: gazdag93@gmail.com \\ Szirbik Sándor \\ egyetemi docens, Miskolci Egyetem, Müszaki Mechanikai Intézet \\ 3515 Miskolc, Miskolc-Egyetemváros, e-mail: sandor.szirbik@uni-miskolc.hu \\ Varga Gyula \\ egyetemi docens, Miskolci Egyetem, Gyártástudományi Intézet \\ 3515 Miskolc, Miskolc-Egyetemváros, e-mail: gyula.varga@uni-miskolc.hu
}

\begin{abstract}
Absztrakt
A tömeg kiegyensúlyozás a forgácsoló eljárások során nagymértékben javitja a forgattyús tengely gyártásakor a gyártmányminöséget és nem mellesleg csökkenti a szerszámgép csapágyazásának terhelését is. A dolgozatban az állandó fordulatszámmal forgó merev testként modellezett egyedi munkadarab tömeg kiegyensúlyozásának hátterét és annak gyakorlati megvalósitását, azaz a szükséges egyedi készülékek tervezését mutatjuk be. Az egyedi ellensúly müködésének eredményességét végeselemes szimulációkkal igazoltuk, amelyekböl csapágyerök csökkenése kitünik.
\end{abstract}

Kulcsszavak: forgattyús tengely, kiegyensúlyozás

\begin{abstract}
Mass balancing in crankshaft manufacturing processes significantly improves the workpiece quality and reduces bearing loads on machine tools. We present the background of mass balancing for a special crankshaft modeled as a rigid body rotating at a constant angular speed and its practical implementation and design steps of the necessary unique devices. The utility of the counterweight can be verified by finite elements analyzes which is indicated that the bearing loads can be also reduced.
\end{abstract}

Keywords: crankshaft, mass balancing

\section{Bevezetés}

A megmunkálás során, különböző okokból fellépő mechanikai rezgések mindig hatással vannak a gyártmányminőség alakulására. A minőségi jellemzők közül is leginkább a megmunkálás során előállított felületek mikrogeometriai jellemzőire van ráhatásuk. A rezgések következtében a szerszámél által leírt burkolófelület és a munkadarab elóállítani kívánt elméleti profilja nem esik egybe. Természetesen mikrogeometriai hibák csak egy részét okozzák rezgések és ezek hatásának mértéke elfogadható, míg a minőségi jellemzők bizonyos határon felüli romlását nem eredményezik.

A rezgéscsökkentés megvalósítását nem csak a kívánt gyártmányminőség garantálása indokolja, hanem a megmunkáló szerszámgép szerkezetei elemeit érő igénybevételek csökkentése, és ezáltal azok élettartamának növelése. Forgácsoló megmunkálásoknál azokat a rezgéseket, amelyeket külső hatás hoz létre: kényszerrezgéseknek, azokat pedig amelyeket maga a forgácsleválasztási folyamat, 
vagyis a szerszámél és munkadarab érintkezési környezetében lejátszódó jelenségek indukálnak, valamint tartanak fent: öngerjesztő rezgéseknek nevezik [1].

Kényszerrezgések jellegzetes típusai [1]:

- aljzatról a gépre átadódó rezgések (pl.: egyéb gépek, utcai forgalom stb. által),

- gép hajtómüvének hibái (pl.: fogaskerék profilhiba általi szögsebesség ingadozás),

- gépelemek közötti játékok (pl.: csapágyak futáshibája),

- forgórészek kiegyensúlyozatlansága (tehetetlenségi erők fellépése),

- szerszámkonstrukcióból adódó szakaszos forgácsleválasztás (pl.: marás).

Öngerjesztő rezgések fő kiváltó okai [1]:

- tribológiai okok (egyenlötlen súrlódási-kenési viszonyok, zárványok stb.),

- eltérö rugalmassági tulajdonságok (anyag inhomogenitás, anizotrópia).

Ha a vizsgált, adott tengely körül forgó merev test súlypontja nem forgástengelyre illeszkedő, akkor a súlypontban helyettesített tömege körmozgásából adódóan erőgerjesztést okoz a dinamikai rendszerben. Ha ráadásul a forgás tengelye nem párhuzamos a test valamelyik fötengelyével (szöghiba van) az már magában rezgést kelt még akkor is, ha a súlypont a forgás tengelyére eső. A forgattyús sajtóhoz készülő forgattyús tengely súlypontjának, tömegközéppontjának helye az elkészített 3D testmodell alapján könnyedén meghatározható korszerü tervezőprogramok alkalmazásával - lásd 1. ábra.

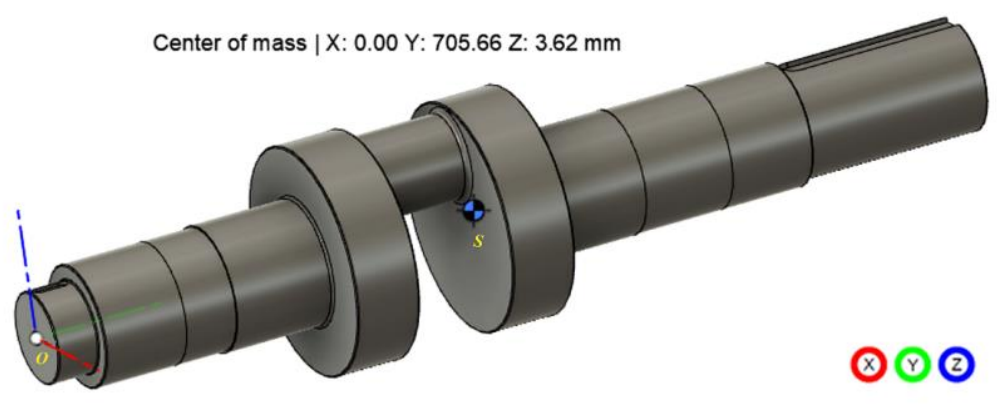

1. ábra. Forgattyús tengely tömegközéppontja.

Az 1. ábrán látható helyzetben lévő $y_{\max }=1490 \pm 1 \mathrm{~mm}$ hosszú forgattyús tengely $\mathrm{S}$ tömegközéppontja az $y_{S}=755,66 \mathrm{~mm}$ helyen, az $y$ forgási tengely felett $z_{S}=3,62 \mathrm{~mm}$-re található. Egyéb intézkedés hiányában, ekkor $y$ körüli forgáskor centrifugális erő fellépésével, azaz rezgések kialakulásával kell számolni már ebből adódóan is a megmunkálás során, és természetesen a geometriai kialakításból adódóan a forgás tengelye nem fötengely probléma is fennáll.

A fellépő erő eltérő mértékủ attól függően, hogy a fő forgástengely vagy a forgattyúcsap középtengelye körül van forgatva az alkatrész. Üzemeltetés során - a beépítési környezetben - a tengely a csapágyhelyek által kijelölt fő forgástengely körül forog. A müveletek tervezésénél meghatározott megmunkáló eljárások során azonban az alkatrészt, a forgattyúcsap tengelye körül is meg kell forgatni, amely ekkor lényegesen nagyobb centrifugális erő megjelenését eredményezi az ekkor megjelenő, jóval nagyobb kiegyensúlyozatlan tömeg miatt.

\section{Kiegyensúlyozás lehetőségei a munkadarab megmunkálása során}

A kiegyensúlyozatlan forgó testek által gerjesztett mechanikai rezgések kiküszöbölésének módja a kiegyensúlyozás. A forgórész merev testként és rugalmas kontinuumként is modellezhető, de általá- 
ban, ha a legkisebb saját körfrekvencia felénél kisebb a forgás szögsebessége, akkor a merev test modell is elegendő [2]. Az elmélet alapján a merev testként vizsgált forgórész statikusan és dinamikusan kiegyensúlyozható. Statikus kiegyensúlyozásra van szükség, ha a forgás tengelye nem megy át az adott merev test tömegközéppontján, de egyébként a megfelelő fötengelye párhuzamos a forgástengellyel. Ezen eljárás során az alkatrészhez póttömeg hozzáadásával, vagy éppen tömeg elvételével (pl.: fúrás) elérhető, hogy a tömegközéppont a kívánt forgási tengelybe tolódjon, ezáltal megszűnjön a nem kívánatos tehetetlenségi erőből adódó rezgés. A kiegyensúlyozás ekkor statikus helyzetben, a test üzemszerü forgatása nélkül elvégezhető (pl.: köszörükorong kiegyensúlyozása prizmán) [3]. Ez a típusú kiegyensúlyozási módszer értelemszerüen leginkább vékony, tárcsaszerü alkatrészeknél alkalmazható eredményesen. A statikus kiegyensúlyozás kivitelezésének elvi bemutatása a 2. ábrán látható.

A kiegyensúlyozó tömeg értéke gyorsan meghatározható a nem forgási tengelyre eső $S$ súlypontban helyezett $m$ össztömegre, vagy csak magára a kiegyensúlyozottságot sértö tömegre forgás közben ható centrifugális erőt kioltó ellenerő felírásából, amelynek közös a hatásvonala, nagysága azonos, iránya pedig következésképp ellentétes a kiegyensúlyozatlanságot okozó hatással. A fellépő centrifugális erő nagysága a 2 . ábra alapján

$$
F_{c f, 1}=m r \omega^{2}
$$

megállapítható, míg

$$
F_{c f, 2}=m_{b} R \omega^{2}
$$

az $R$ sugáron, $\omega$ szögsebességgel forgó kiegyensúlyozó $m_{b}$ tömegre ható centrifugális erő nagysága, így a statikus kiegyensúlyozottság

$$
F_{c f, 1}=F_{c f, 2}
$$

feltételéből az $S$ pont forgástengelytől mért $r$ távolságából, az excentricitásból meghatározható a centrifugális erő, illetve az ezzel kapcsolatba hozható csapágyerök mérése útján.

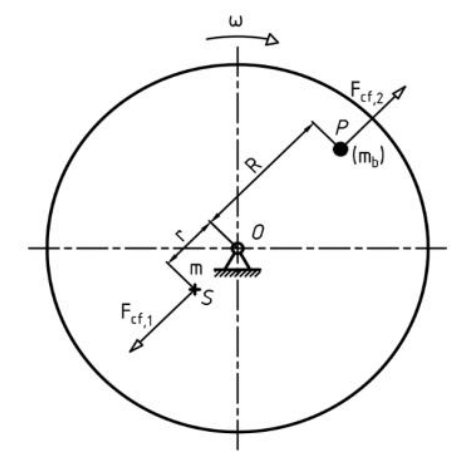

2. ábra. Statikus kiegyensúlyozás megvalósitásának elvi módja.

Ebben az egyszerü esetben a kezdeti excentricitást állandónak véve, továbbá adottnak a kiegyensúlyozást végző tömeg $R$ távolságát

$$
m_{b}=m \frac{r}{R}
$$

lesz a szükséges ellenoldali kiegyensúlyozó tömeg nagysága. 
Dinamikusan kiegyensúlyozatlan merev testnek tekintett forgórésznek a forgás tengelye nem valamelyik súlyponti (tömegközépponton átmenő) tehetetlenségi fötengelye. Ekkor a forgás során fellépö tehetetlenségi erő nyomatékot (erőpárt) is létrehoz, amely végső soron a kialakuló rezgések miatt szintén az alátámasztási helyeket (csapágyazást) veszi igénybe [4], [5]. A dinamikus kiegyensúlyozás, a kiegyensúlyozás egy általánosabb esetét jelenti, amelyben a statikus kiegyensúlyozást is elvégezzük. A bizonyíthatóan szükséges két kiegyensúlyozó síkban felszerelt póttömegek megfelelő értékének és helyzetének megválasztásával elérhető, hogy az így modifikált forgórésznek a forgástengely már súlyponti tehetetlenségi fötengelye is legyen, és átmenjen a tömegközépponton [2]. Az elhanyagolható tömegü merev tengelyre szerelt forgórész dinamikus kiegyensúlyozás megértéséhez szükséges modell elvi vázlatát a 3 . ábrán látható.

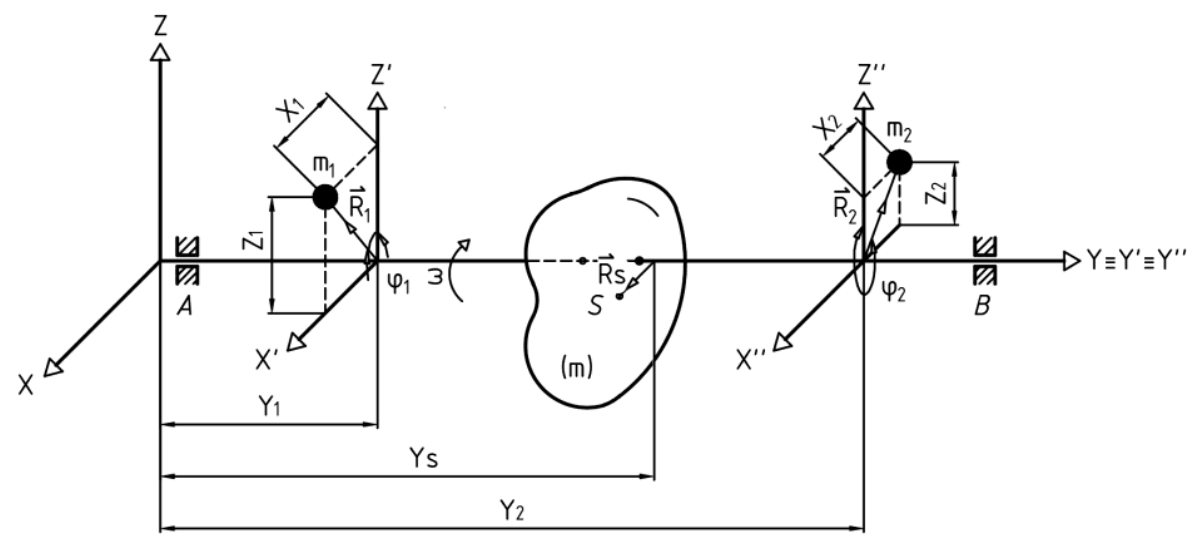

3. ábra. Dinamikus kiegyensúlyozás általános esetben.

A két kompenzáló tömeggel együtt a forgórész forgástengelyre számított statikai nyomatéka zérussá tehetö, azaz

$$
m \vec{R}_{S}+m_{1} \vec{R}_{1}+m_{2} \vec{R}_{2}=\overrightarrow{0},
$$

biztosítja a statikus kiegyensúlyozást. A forgórész és a két póttömeg együttesének tehetetlenségi fötengelyévé válik az y tengely, ha teljesül a

$$
J_{x y} \vec{e}_{x}+J_{z y} \vec{e}_{z}+m_{1} \vec{R}_{1} y_{1}+m_{2} \vec{R}_{2} y_{2}=\overrightarrow{0}
$$

vektoregyenlet is, azaz a póttömegekkel módosított rendszer $\underline{=}_{S}^{m}$ tehetetlenségi tenzorában az y tengelyhez tartozó oszlopból a síkpárra számított tehetetlenségi nyomatékok eltünnek: $I_{x y}^{m}=J_{z y}^{m}=0$, azaz

$$
\vec{e}_{y} \times\left(J_{S}^{m} \cdot \vec{e}_{y}\right)=\overrightarrow{0} .
$$

A felírt (5) és (6) vektoregyenletben az $m_{1}, x_{1}, y_{1}, z_{1}, m_{2}, x_{2}, y_{2}, z_{2}$ megválasztható mennyiségek, míg $m, J_{x y}, J_{z y}$ a kiegyensúlyozatlan forgórészre vonatkozó ismert adatok. Az (5) és (6) egyenletekből származtatható négy feltételi skaláregyenletből négy ismeretlen paraméter értéke számítható, a többit pedig rögzítenünk kell. Általában a kiegyensúlyozó tömegek, forgástengelyre meröleges síkjainak $y_{1}$ és $y_{2}$ távolságát, és ezen síkokon a forgástengelytöl mért sugarakat szokás megválasztani adottnak. Ekképpen a tömegek elhelyezéséhez szükséges 


$$
\varphi_{1}=\arctan \left(\frac{J_{x y}-m x_{S} y_{2}}{J_{z y}-m z_{S} y_{2}}\right), \quad \varphi_{2}=\arctan \left(\frac{J_{x y}-m x_{s} y_{1}}{J_{z y}-m z_{S} y_{1}}\right)
$$

$x$ tengellyel bezár szögek a felvett kiegyensúlyozó síkokban, valamint az:

$$
m_{1}=\frac{\sqrt{\left(J_{z y}-m z_{S} y_{2}\right)^{2}+\left(J_{x y}-m x_{S} y_{2}\right)^{2}}}{R_{1}\left|y_{2}-y_{1}\right|}, \quad m_{2}=\frac{\sqrt{\left(J_{z y}-m z_{S} y_{1}\right)^{2}+\left(J_{x y}-m x_{S} y_{1}\right)^{2}}}{R_{2}\left|y_{1}-y_{2}\right|}
$$

kiegyensúlyozó tömegek értéke képletben megadható a levezetést itt mellőzük [2].

A forgástengely megmunkálása során annak skalárjellemzői változnak, például a forgács formájában leválasztott anyagtérfogattal arányosan, folyamatosan csökken a tömeg, folytonos függvény szerint változhat a tömegközéppont helye, folytonosan változhatnak a tehetetlenségi fötengelyek helyzetei stb. Felmerül a kérdés, hogy megmunkálás közben a kiegyensúlyozást a munkadarab melyik állapotára célszerü elvégezni. Legkielégítőbb megoldás lenne, ha minden egyes időpillanatban az alkatrész kiegyensúlyozott lenne végig a megmunkálás alatt. Ez a feltétel viszont azt igényelné, hogy a kiegyensúlyozó tömegeknek a nagysága, illetve azok elhelyezése, időben folytonosan változtatható legyen. Ezen feltétel kielégítése a kereskedelemben jelenleg fellelhető készülékekkel lényegében kivitelezhetetlen.

Jelen esetben a kiegyensúlyozás a munkadarab végállapotára, tehát az elkészült alkatrészre végzett. Ennek legfőbb indoka, hogy a minőségi követelmények, a megmunkálás során, technológiai folyamatszakaszonként folyamatosan szigorodnak, míg a befejező megmunkálás során, érik el a végső, alkatrészrajz szerinti követelményeket. Az egyes technológiai folyamatszakaszokba tartozó müveleteknél, a müveleti ráhagyások szolgálnak a megmunkálási hibák figyelembevételére és ezen ráhagyások értéke egyre kisebb értékủ minél előrébb haladott az alkatrész állapota a technológiai folyamatban. Addig tehát, amíg mondjuk nagyoló megmunkálásnál egy ismert vagy ismeretlen forrásból származó megmunkálási hiba kompenzálása fedezhető a nagyolási ráhagyásból, egy befejező megmunkálás esetében, a jóval kisebb értékű simítási ráhagyás már közel sem biztos, hogy elegendő ugyanerre és akkor a munkadarab selejtté válhat. Ezen okokból kifolyólag is kedvező például, hagyományos megmunkálási müveletek (külön marógépen vagy fúró-marómüvön végezve a marási müveleteket, illetve esztergagépen végezve az esztergálási mủveleteket) alkalmazása során - a forgattyúcsap marással történő előnagyolása (4. ábra).

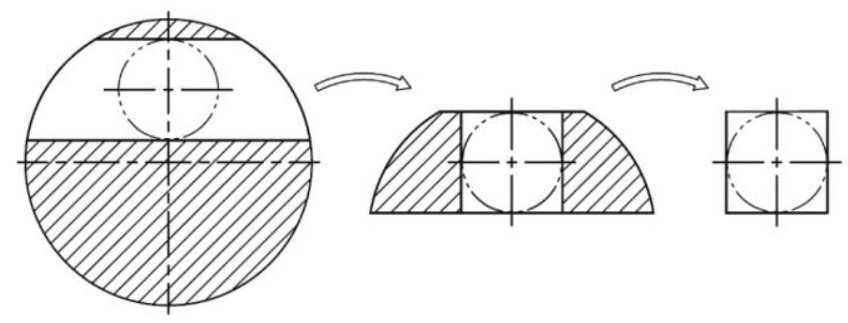

\section{4. ábra. Forgattyúcsap marással történö elönagyolása.}

Ha „teliből”, tehát jelen esetben: a kovácsolt hengeres felületből, kizárólag esztergálási műveletekkel kerülne kialakításra, az ezen hengeres felülethez képest excentrikus elhelyezkedésü forgattyúcsap és ekkor például, ha a mủvelet végállapotára van kiszámítva a szükséges ellensúlyok nagysága és elhelyezése, akkor a mủvelet elején kellene kiegyensúlyozatlanság miatt fellépő fokozott csapágyterhelések megjelenésével számolni a szerszámgépen. Ekkor a müvelet kezdetén felszerelt ellensúlyok, amelyek a müvelet végére kialakított nagyolási ráhagyással ellátott forgattyúcsap kedvezőtlen hatását hiva- 
tottak ellensúlyozni, épp maguk okoznák a kiegyensúlyozatlanságot és ez csak a müvelet elörehaladtával fokozatosan mérséklödne, majd szünne meg. Köztes megoldás lehetne esetleg, ha müvelet közben, bizonyos meghatározott ráhagyás leválasztása után - mintegy megszakítva a megmunkálást - az ellensúlyok értékét és elhelyezését korrigálnák. Ez azonban az üzemi gyakorlatban nehezen kivitelezhető, az így keletkező mellékidők miatt.

A forgattyús tengely megmunkálásának különböző müveleteinél, azt a fő forgástengely, illetve a forgattyúcsap forgástengelye körül egyaránt forgatni szükséges, esztergálási és köszörülési müveletek keretében is. Ez eltérö kiegyensúlyozó tömegek meghatározását teszi szükségessé. A 3. ábrán látható modell esetében az y forgástengely körül forog $\omega$ szögsebességgel a kiegyensúlyozatlanságot okozó tömeg.

Ezek alapján a kiegyensúlyozó tömegek meghatározásakor a forgattyús tengely alkatrészt is célszerü két részre bontani attól függően, hogy az alkalmazott modell szerint éppen melyik rész testesíti meg a kiegyensúlyozatlanságot jelentő tömeget, mivel az elmélet szerint is az adott forgástengelyre szimmetrikus elrendezésü térfogatrész eleve kiegyensúlyozott és úgymond ez van elrontva (5. ábra). A forgattyús tengely kiegyensúlyozás szempontjából történő részekre bontása láható a 5. ábrán.

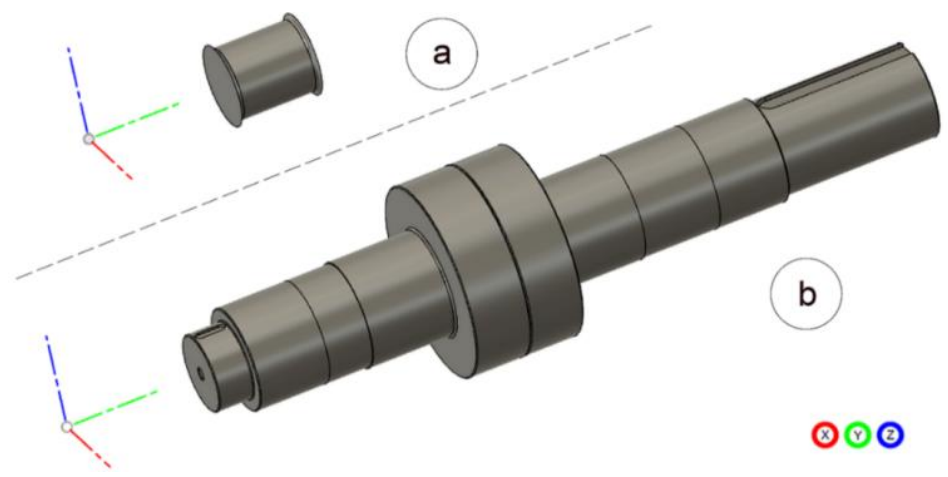

5. ábra. Forgattyús tengely felbontása (a) forgattyúcsapra és (b) alaptestre.

A forgattyúcsap (a) $m_{a}=15,5 \mathrm{~kg}$, az alaptest (b) $m_{b}=368,8 \mathrm{~kg}$ tömegü, míg tömegközéppontjaikban

$$
\left[J_{S, a}\right]=\left[\begin{array}{ccc}
0,046 & 0 & 0 \\
0 & 0,033 & 0 \\
0 & 0 & 0,046
\end{array}\right] k g m^{2} \quad\left[J_{S, b}\right]=\left[\begin{array}{ccc}
38,72 & 0 & 0 \\
0 & 3,09 & 0,042 \\
0 & 0,042 & 38,73
\end{array}\right] k g m^{2}
$$

tehetetlenségi tenzorok adódnak. Látható, hogy az alaptest mátrixában a mellékátlóban is van elem. Ezek az ún. deviációs nyomatékok azért jelentkeznek, mert a test az $x-y$ síkra nem szimmetrikus, a két reteszhorony megléte miatt.

A forgattyúcsap tömegközéppontja alaptest forgástengelytől mért távolsága éppen a forgattyúsugárral egyezik meg, amely az alkatrészrajz szerint $z_{S, a}=95 \mathrm{~mm}$. Az alaptest tömegközéppontja $-\mathrm{a}$ reteszhornyok hatása miatt - mintegy 0,2 $\mathrm{mm}$-el e tengely alatt helyezkedik el. Ezen eltérés olyan csekély, hogy ezt a továbbiakban elhagyjuk és amikor az alaptest tölti be a kiegyensúlyozatlan tömeg szerepét. Esztergálási mủveleteknél $R=0,5 \mathrm{~m}$ értéküre állított a kiegyensúlyozó tömegek elhelyezésének sugara. Ezekhez a müveletek elvégzéséhez választott esztergára, $\emptyset 1250 \mathrm{~mm}$ méretủ síktárcsa felszerelhető és ezen készüléken a kiegyensúlyozó tömegek is elhelyezhetők. Köszörülési műveleteknél, a megmunkáló gép munkaterének korlátai miatt, $R=0,15 \mathrm{~m}$ értékűnek választott a tömegek elhelyezésének sugara. A kiegyensúlyozást igénylő műveleteknél, a kiegyensúlyozó síkok forgástengelyen mért 
hosszkoordinátáit $\left(y_{1} ; y_{2}\right)$, a kiegyensúlyozó tömegek, kiegyensúlyozó síkokban mért sugarait $\left(R_{1} ; R_{2}\right)$ így megválasztva, a kiegyensúlyozó tömegek elhelyezési szögeit $\left(\varphi_{1} ; \varphi_{2}\right)$, illetve a kiegyensúlyozó tömegek értékekeit $\left(m_{1} ; m_{2}\right)$ a (8) és (9) összefüggésekböl számíthatók.

A forgattyúcsap megmunkálásának múveletinél jóval nagyobb tömegek szükségesek a kiegyensúlyozáshoz, mint az alaptestet érintő müveleteknél, hiszen ekkor az alaptest tömege okoz kiegyensúlyozatlanságot. A megmunkálás közbeni kiegyensúlyozás több szempontból összetettebb, mint egy elkészült alkatrész kiegyensúlyozásának elvégzése. Ennek főbb okai:

- geometriai jellemzők időben folytonos változása,

- több tengely körüli forgatás szükségessége,

- felfogásnál alkalmazott készülékek kiegyensúlyozásra gyakorolt hatása,

- kiegyensúlyozó tömegek elhelyezése nem korlátozhatja felületek megmunkálását.

Ezek alapján belátható, hogy megmunkálás során nem lehet reális célkitüzés, minden műveleten belül, a megmunkálás minden időpillanatában, a munkadarab kiegyensúlyozottságának biztosítása. A dinamikus kiegyensúlyozásnál a két síkban elhelyezendő kiegyensúlyozó tömegek szükségessége hatással van a felfogó készülékek típusának megválasztására. Előfordulhatna például, hogy a szerszámgép szegnyergére is síktárcsát kellene szerelni, amelynek méretei korlátozottak, jellemzően kisebb méretben alkalmazható, mint a föorsóra szerelt elsődleges síktárcsa, ez pedig a csökkenő geometriai méret miatt nagyobb kiegyensúlyozó tömegek alkalmazásának szükségességét eredményezi az érintett kiegyensúlyozó síkban. Továbbá, ebben az esetben a kiegyensúlyozó tömegek elhelyezése, amelyet vagy a befogó alapkészülékre, vagy magára a munkadarab valamely felületére kellene szerelni, akadályozhatja az adott mủveletben érintett felületek megmunkálását.

Ezen, a technológiát érintő kedvezőtlen hatások miatt a dinamikus kiegyensúlyozás lehetőségéről megmunkálás során a továbbiakban lemondva csak a statikus kiegyensúlyozás megvalósítása történik meg az érintett müveleteknél, azonban a kiinduló kiegyensúlyozatlan állapothoz képest minden esetben már ez is kedvező eredményt hoz, a gerjesztett rezgéseket és a fellépő csapágyerőket illetően.

A statikus kiegyensúlyozás megvalósításához alkalmazandó paramétereket az egyes művelteknél, a 1. táblázat tartalmazza. Az egyedi készülékek tervezésénél a számított tömegek értékeit felfelé, egész számra kerekítettek jelölésük pedig $m_{b}{ }^{\top}$ a korrigált tömeg értékeit szintén lásd a 1. táblázatban. Statikus kiegyensúlyozás alkalmazásakor, a kiegyensúlyozó tömegek a forgástengely mentén bármelyik síkban elhelyezhetök, szöghelyzetüket tekintve pedig a test, forgástengelyre meröleges síkban vett, tömegközéppont eltolódásának irányával ellentétesen történik.

1. táblázat. A statikus kiegyensúlyozás paraméterei müveleteknél.

\begin{tabular}{|c|c|c|c|c|c|}
\hline Ssz. & Mǘvelet & $\begin{array}{c}R \\
{[\mathrm{~m}]}\end{array}$ & $\begin{array}{c}\varphi \\
{[\mathrm{rad}]}\end{array}$ & $\begin{array}{c}m_{b} \\
{[\mathrm{~kg}]}\end{array}$ & $\begin{array}{c}m_{b}{ }^{\prime} \\
{[\mathrm{kg}]}\end{array}$ \\
\hline 4. & Nagyoló esztergálás „A” oldalon & $\mathbf{0 , 5}$ & $\pi$ & 2,95 & 3 \\
\hline 5. & Nagyoló esztergálás „,B” oldalon & $\mathbf{0 , 5}$ & $\pi$ & 2,95 & 3 \\
\hline 6. & Forgattyúcsap nagyoló esztergálása & $\mathbf{0 , 5}$ & $\mathbf{0}$ & 70,07 & 71 \\
\hline 9. & Simító esztergálás „A” oldalon & $\mathbf{0 , 5}$ & $\pi$ & 2,95 & 3 \\
\hline 10. & Simító esztergálás „B” oldalon & $\mathbf{0 , 5}$ & $\pi$ & 2,95 & 3 \\
\hline 11. & Forgattyúcsap simító esztergálása & $\mathbf{0 , 5}$ & $\mathbf{0}$ & $\mathbf{7 0 , 0 7}$ & 71 \\
\hline 14. & Palástköszörülés & $\mathbf{0 , 1 5}$ & $\pi$ & 9,81 & 10 \\
\hline 15. & Forgattyúcsap palástköszörülése & $\mathbf{0 , 1 5}$ & $\mathbf{0}$ & $\mathbf{2 3 3 , 5 7}$ & 234 \\
\hline
\end{tabular}




\section{Egyedi készülékek tervezése a forgattyúcsap megmunkálásához}

A forgattyúcsap palástköszörülési mủveletéhez egyedi ellensúly tervezése a statikus kiegyensúlyozáshoz szükséges tömegek meghatározása alapján (1. táblázat) történik, ezen mủveletnél kell a legnagyobb kiegyensúlyozó tömeggel ellátni a munkadarab-készülék rendszert, a szerszámgép csapágyterheléseinek mérséklése érdekében és itt áll rendelkezésre a legkisebb tér az ellensúlyok elhelyezésére. $\mathrm{A}$ választott palásköszörünek ugyanis kisebb a munkatere, mint a választott $\mathrm{CNC}$ esztergának. Az egyéb mủveleteknél szükséges ellensúlyok tervezése nem lett elvégezve, figyelembe véve, hogy azok kisebb tömegüek, illetve nagyobb tér áll rendelkezésre az elhelyezésre. Ebben az esetben kielégítö eredmény érhető el kiegyensúlyozást illetően, kereskedelemben kapható súlyok, egyetemes készülékekre (pl.: síktárcsa) való felszerelésével. Tekintettel a szerszámgép munkatér jelentette korlátra, a kiegyensúlyozáshoz szükséges $m_{b}{ }^{\prime}$ tömeg értékét - önkényesen megválasztva - két részre bontjuk:

$$
m_{b}{ }^{\prime}=234 \mathrm{~kg}=m_{b, 1}{ }^{r}+m_{b, 2}{ }^{\prime}=120 \mathrm{~kg}+114 \mathrm{~kg}
$$

Az érintett műveletben $m_{b, 1}{ }^{2}$ résztömeg, a köszörüre szerelt síktárcsára elhelyezhető és így $m_{b, 2}{ }^{2}$ résztömeg értékét veszük alapul, a munkadarabra szerelhető, egyedi ellensúly tervezésekor. Az ellensúly munkadarabhoz történő illesztésére leginkább két felület mutatkozik alkalmasnak, melyek: $\emptyset 140 h 7\left({ }_{-0,04}^{0}\right) \mathrm{mm}$ és $\emptyset 170 h 7\left({ }_{-0,04}^{0}\right) \mathrm{mm}$ átmérőkkel jellemezhető hengeres felületek. Ezeknek a felületeknek a méret-, alak- és helyzettürése kellő szigorúsággal bír, a szükségesen pontos illeszkedés megvalósíthatóságához. További fontos tényezö, hogy ezen felületek a köszörülési müveletek megkezdésekor már hordozzák a két reteszhornyot, amelyek felhasználhatók az ellensúly menesztésére, ezáltal biztosítható a munkadarab és az ellensúly azonos szögsebeséggel, együtt forogjanak a müveletben.

Az ellensúly illesztésére az $\emptyset 140 h 7\left({ }_{-0,04}^{-}\right) \mathrm{mm}$ átméröjü, rövidebb tengelyvéget használjuk. Ennek indoka, hogy az ellensúly illesztés megvalósítására szolgáló, agyrészének középvonala, a munkadarab fö forgástengelyében helyezkedik el. Így az ellensúly azon tömegközéppont eltolódást ezáltal kiegyensúlyozatlanságot okoz a forgattyúcsap megmunkálásakor és ennek mérséklése érdekében célszerủ, ha az ellensúly agyrésze minél kompaktabb, azaz a rövidebb tengelyvégre szerelt. Az is előfordulhat, hogy az agyrész kialakítása miatt nem lehet meghatározott tömegü, illetve tömegközéppontú ellensúlyt megkonstruálni, hiszen a nagyméretű agyrész tömege, olyan mértékben a kedvezötlen irányba tolja el a tömegközéppontot, hogy annak kívánt helyzetbe történő hozása, már csak olyan fokozott, az ellensúly többi rész által képviselt tömeggel valósítható meg, amely az egész ellensúly össztömegének már az elöírttól nagyobb értékét eredményezi. Vagyis ekkor hiába jó helyre került a tömegközéppont, az ellensúly tömege már nem megfelelő és ekkor az ellensúly nem teljesíti az elvárt funkcióját.

Az ellensúly tervezésekor az alábbi lépések történnek:

- ellensúly geometriájának felvétele,

- geometriában elemek kijelölése, melyeknek tömege szabadon változtatható,

- ellensúly tömegének beállítása a változtatható elemekkel,

- változtatható elemek transzlációs mozgatásával, a súlypont helyzetének beállítása,

- egyéb konstrukciós kiegészítések,

- súlypont és tömeg ellenőrzése.

Ideális ellensúly lenne, egy a kívánt $\left(m_{b, 2}{ }^{\prime}=114 \mathrm{~kg}\right)$ tömeggel bíró tömegpont súlytalan rúddal, a kívánt kiegyensúlyozási sugáron $(R=0,15 \mathrm{~m})$ csatlakozva a munkadarabhoz. Valóságban a tömeg térbeli eloszlása és az egyéb szükséges konstrukciós elemek (agyrész, merevítés stb.) miatt adott geometria és , beállított” tömeg esetén, a kijelölt változtatható elemmel csak bizonyos tartományon belüli 
súlyponteltolódás érhető el. Minél inkább eltér az ideális esettől az ellensúly felépítése - például a forgástengelytől távol elhelyezkedő, nagyméretű agyrész miatt - ezen tartomány egyre szükül, majd végül az is elöfordulhat, hogy ezen tartomány akár meg is szünik. A feladat ekkor nem oldható meg az adott geometria esetén.

Az ismertetett lépések, illetve szempontok szerint tervezett ellensúly $3 D$ modellje látható az 6 . ábrán. Ez egy hegesztett konstrukció, amely segítségével az anyagtakarékosság, illetve gyártási költség csökkentése jól érvényesíthető. Egy ilyen egységnél hegesztés után mindenképpen szükség van feszültségcsökkentő hőkezelésre is. Forgácsoló eljárással csupán az agyrész furatát és homloklapját, az agyban található reteszhornyot, illetve a változtatható elemek oldalfelületét kell megmunkálni. A változtatható elemeket ez esetben, az alaplemezre szimmetrikusan hegesztett, bordákkal merevített, íves komponensek jelentik. Az ellensúly hegesztési összeállítási rajzait a [9] diplomaterv tartalmazza.

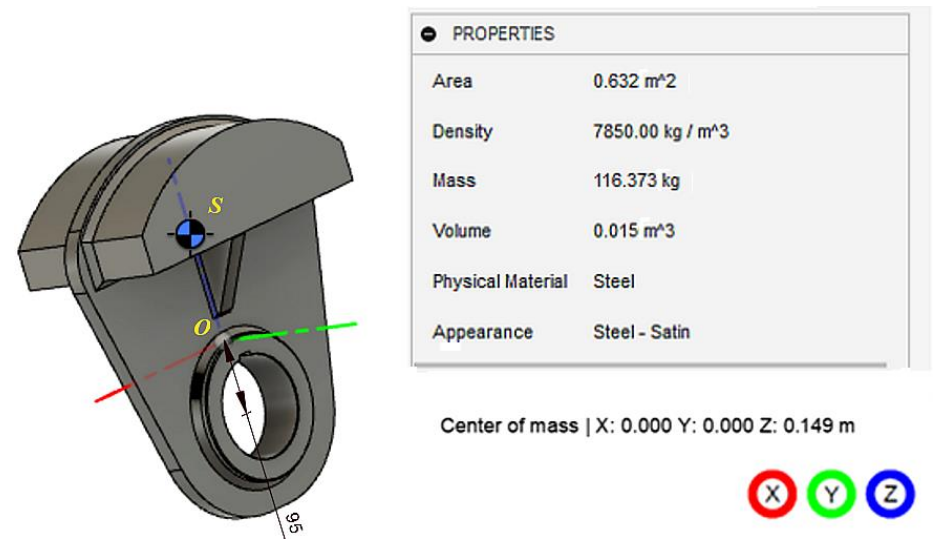

6. ábra. Hegesztett kivitelü ellensúly és jellemzöi.

A megtervezett ellensúlyt alkalmazását a forgattyúcsap palástköszörülési műveleténél, technológiai dokumentációkban kell elöírni. Az ellensúlyt a tengelyre kell szerelni, mivel a megmunkáláshoz választott köszörün más módon nem lehet súlyt elhelyezni. Az ellensúly munkadarabra történő szerelésekor, annak tengelyvéghez képesti elfordulása meggátolható, [6] szabvány szerinti: bxh $x l=20 \mathrm{~mm} \times 12 \mathrm{~mm} \times 56 \mathrm{~mm}$ méretü, fészkes retesz alkalmazásával. A forgattyúcsap köszörülési müveleténél az ellensúly tengelyvégre történő szerelésének modellje látható a 7. ábrán.

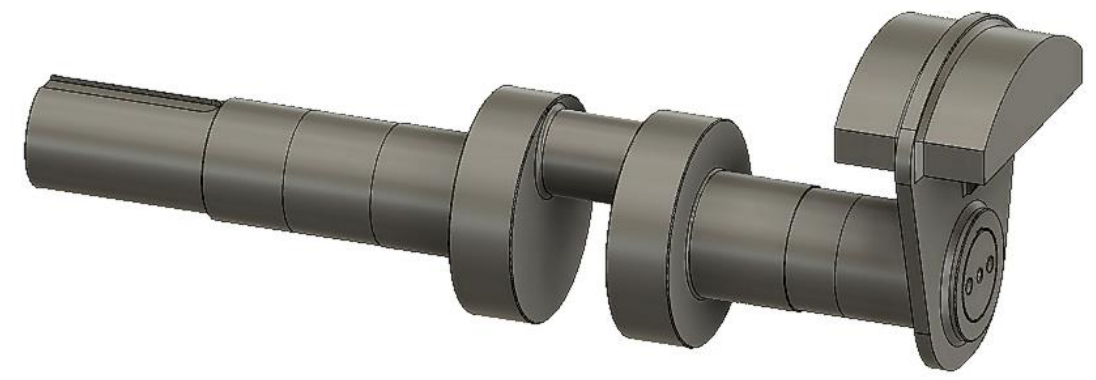

7. ábra. Tengelyvégre szerelt ellensúly forgattyúcsap köszörülési müveleténél.

A külpontosság pontos betartását biztosító egyedi lökettárcsák tervezése is szükséges, amelyek a forgattyúcsap nagyoló és simító esztergálási, illetve köszörülési müveleteinél is alkalmazhatók. Itt 
kedvező, ha a készülék nem illeszkedik a munkadarab egyik átméröjéhez sem, hiszen azok mérete a különböző műveletek során alakul. Átmérőn történő illesztéskor vagy beállítható méretű kompenzátor tagra vagy müveletek során cserélhető, célszerü kiegészítő tagra lenne szükség, amelyekkel a megfelelő illeszkedés biztosítható különböző átmérők esetén. Ilyen esetekben hátrány egy nagyoló megmunkálással előállított hengeres felülethez való illesztés, mert az - technológiai okokból kifolyólag - még nem lehet kellően szabatos. Ezek figyelembevételével, a készülék munkadarabhoz való helyzete meghatározására az alkatrész véglapjai alkalmasak, amelyekre a helyesbített alkatrészrajzon szigorított geometriai türések lettek elöírva. Ezen jellemzők elő́llítása simító marási müveletelem keretében történik, akár a nagyoló esztergálást megelőző véglapmegmunkálásról legyen szó vagy a nemesítő hőkezelés utáni véglap szabályozásról. A véglapokon elhelyezett, dörzsárazott $\emptyset 24 \mathrm{H7}\left({ }_{0}^{+0,021}\right) \mathrm{mm}$ furatok egyaránt szolgálnak a szerelt kivitelü készülék tájolására, illetve közvetítik a szerszámgépről a munkadarabra átvinni kívánt teljesítményt, amely a forgattyúcsap forgácsolási müveleteihez szükséges.

Ezen egyedileg gyártandó kötőelem felépítése megegyező a [7] szabvány elöírásaival, azzal a különbséggel, hogy jelen esetben az illesztésre szolgáló, alkatrészrajzon elöírt $\emptyset 24 h 7\left({ }_{-0,021}^{0}\right) \mathrm{mm}$ átmérö mérettürése és annak IT7 türésosztálya, szigorúbb a szabványban elöírt IT11 tủrésosztálynál, így kisebb játékkal szerelhető a készülék, ami kedvező a megmunkálási pontosságra nézve. Ezen felül az illesztésre szolgáló $\emptyset 24 h 7\left({ }_{-0,021}^{0}\right) \mathrm{mm}$ hengeres felület hossza is eltérö a szabványban elöírttól, a nagyobb terhelhetőség érdekében növelhető. Az $M 20$ menetes rész axiális irányú biztosításra szolgál. Legfőbb funkciója jelen esetben, hogy megmunkálás közben a csapszeg ne rázkódhasson ki helyéről a megmunkálás folyamán. A menetes csapszeg feje alá [8] szabvány szerinti: A24 típusú alátét szerelendő. A lökettárcsák munkadarabhoz történő szerelési műveletének komponensei láthatók a 8. ábrán. Az alkatrészek véglapokhoz történő szerelésekor minden esetben szükség van két-két darab alátétre és menetes csapszegre is.

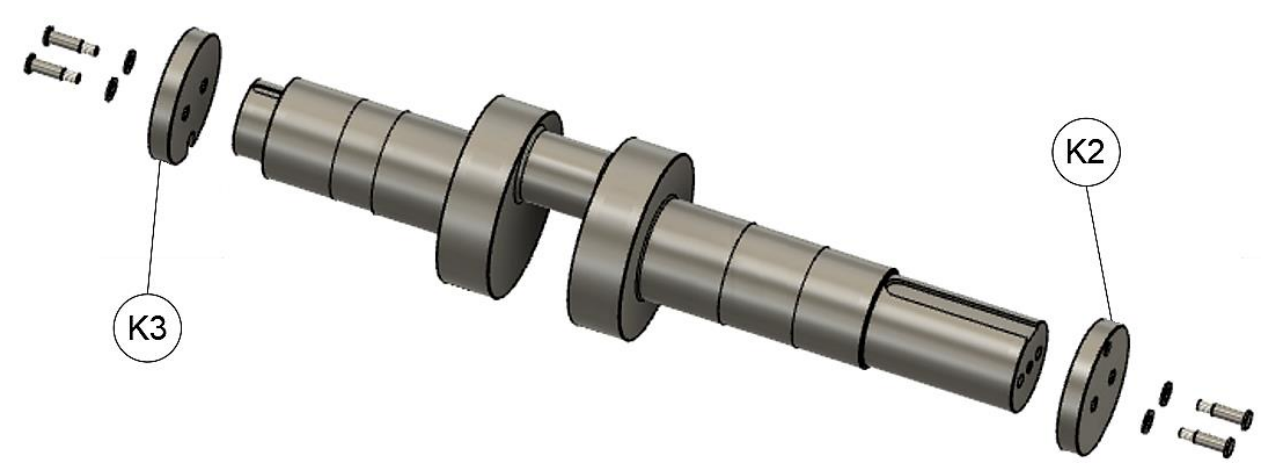

8. ábra. Lökettárcsák tengelyvégekre történö szerelése.

\section{Kiegyensúlyozás végeselemes analízise}

A munkadarab és készülékek rendszerét együttesen kell vizsgálni a kiegyensúlyozás végeselemes ellenőrzésekor. A szerszámgépre átadódó terhelések vizsgálatához azonban további részek modelljének csatolása is szükséges. Ezeket a modellelemeket a szerszámgép azon elemeit testesítik meg együttesen, amelyek a megmunkálás közbeni terhelések közvetítésében szerepet játszanak, egészen a szerszámgép csapágyazásig terjedően, hiszen az itt fellépő reakcióerőket kell vizsgálni, mert a kívánt gyártmányminőség garantálása mellett a szerszámgép csapágyterheléseinek csökkentése is célkitüzés. 
Ezen elemek egyszerüsítve és összevontan modellezettek. Jóllehet a valóságban több gépelemből álló egységekröl van szó, azonban a konkrét szerszámgép felépítés pontos ismeretének hiányában, erre nincs lehetőség. Ezek szerint az egyik elem lényegében felfogható: föorsó-síktárcsa-esztergacsúcsmenesztő készülékelem összevonásaként és ez az elem kiegészül még a felszerelt ellensúllyal is a kiegyensúlyozást vizsgáló esetben. A másik elem pedig értelmezhető esztergacsúcs-szegnyereghüvely összevonásaként. Az összevont fiktív egységek felépítése és a munkadarab-készülék rendszerrel való kontaktusa látható a 9. ábrán már a tárcsán lévő hengeres testtel, mint kiegyensúlyozó tömeggel együtt szerelten modellezve, az eredeti állapotot szimuláló modellből ez hiányzik.

A végeselemes elemfajták közül az igen hatékonynak bizonyuló 10 csomópontú, izoparametrikus tetraéder elemet választottuk, amellyel a tetszőleges alakú térfogat nagy pontossággal leírható: Négy csomópont az elem sarokpontját és további hat az oldalak felezőpontját határozza meg. Így lehetőség van a görbült oldalak íves elemekkel történő leírására. A végeselemes modell a geometriai méretek 3\%-os nagyságával, mint átlagos elemmérettel konstruált háló alkalmazásával valósult meg. Így a szoftver által megkülönböztethető, tipizált felületek esetében eltérő sürüségü hálósürüség adódott a geometriai kiterjedés függvényében.
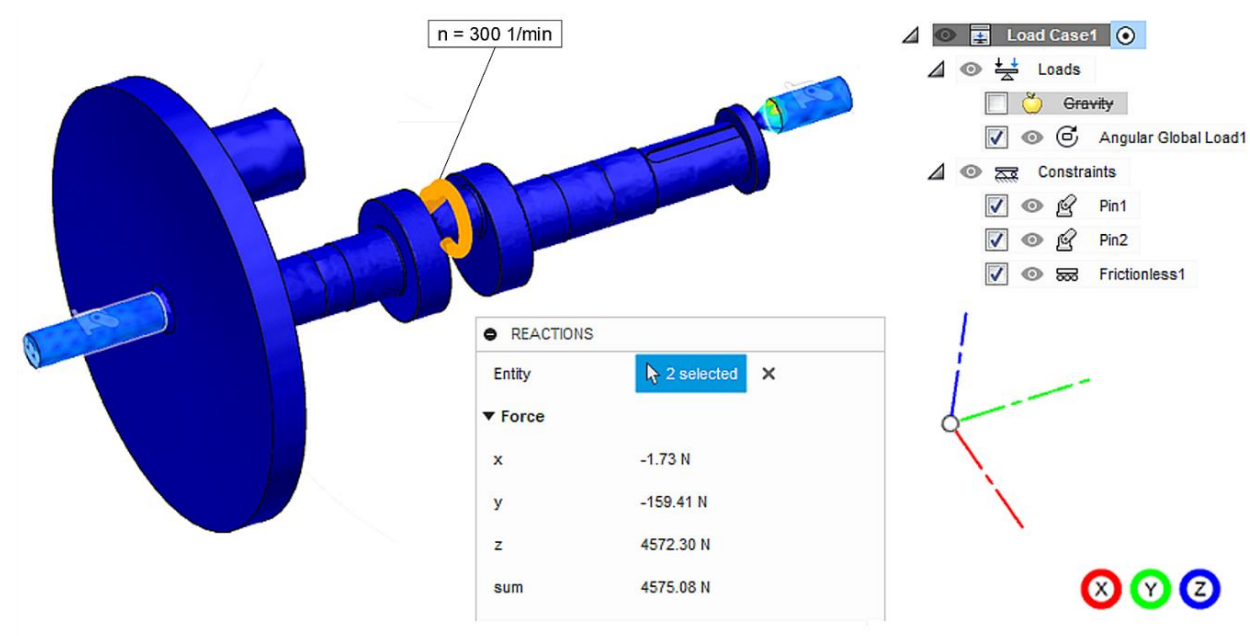

9. ábra. Kiegyensúlyozás utáni csapágyerök szimulációja.

A főorsó csapágyhelyként értelmezett, külső hengeres felületen a radiális mozgás gátolt, míg a szegnyereghüvely csapágyazásként értelmezett, külső hengeres felületen emellett az axiális mozgás is zérusnak rögzített. Mivel tisztán a kiegyensúlyozatlanságból származó terhelés mértékéről és jellegéről szeretnénk képet kapni így a modellen terhelésként, kizárólag a forgásból adódó terhelés értelmezett, az önsúly nincs figyelembe véve. A megmunkáláshoz választott CNC eszterga maximális, állandósultnak tekintett $(n=300$ 1 $/ \mathrm{min})$ fordulatszámából számított szögsebesség mellett a terhelést felvéve a két nevesített csapágyhelyen együttesen számítjuk a reakcióerőt.

Szimulációkat lefolytatva a kiegyensúlyozatlan, valamint egyedi ellensúllyal szerelt kiegyensúlyozott esetre is azt tapasztaljuk, hogy a megmunkálás közbeni kiegyensúlyozás eredményeképpen, a szerszámgép csapágyazás, kedvezőtlen lüktető igénybevételből származó terhelését, mintegy 87\%-kal sikerült csökkenteni a vizsgált végeselemes modell szerint. Az eredeti állapothoz képest, nagyságrendileg kisebb, de nem eltünő kiegyensúlyozatlanság, egyfelől onnan származhat, hogy csak a statikus kiegyensúlyozás megvalósítását tüztük ki célul, másrészt a forgattyúcsap megmunkálhatóságának 
biztosítása céljából megkonstruált készülékelemek maguk is okoznak kiegyensúlyozatlanságot. Fontos megemlíteni, mint kiegyensúlyozást befolyásoló tényezőt még az, hogy a munkadarab rugalmas test, így terhelés hatására alakváltozást is szenved és ez hatással van a kiegyensúlyozásra is. A forgácsolóerő hatásának kitett forgattyús tengely szilárdságtani analízisét a [9] diplomaterv részleteiben is ismerteti.

\section{5. Összefoglalás}

Egyedi készülékek tervezését a hagyományos gyártás indokolja, azaz marógépen marási műveletek a külön esztergagépen pedig az esztergálási műveletek kerülhetnek elvégzésre. A forgattyús tengely forgácsoló megmunkálásakor a nem forgásszimmetrikus geometria forgatásából adódó káros rezgések mérséklése mindenképp szükséges a gyártmányminőség garantálásának és a csapágyterhelések mérséklésének érdekében. A forgattyúcsap palástköszörülésénél, ahol a rendelkezésre álló gép kialakítása nem teszi lehetővé ellensúly rögzítését, tengelyre szerelhető, hegesztett ellensúlyt kellett tervezni.

A bemutatott, tervezési szempontok érvényesítésével konstruált egyedi ellensúly hatékonyságát végeselemes szimulációk által is igazolta a dolgozat, bővebben a [9] diplomamunka. Összevetésre kerültek a kiegyensúlyozatlan, valamint az egyedi ellensúllyal szerelt esetekben fellépő csapágyerök. A munkadarab megmunkálás szimulációja az állandó fordulatszámmal forgatott esetben, a szerszámgép csapágyazásig vizsgált egyszerüsített modelljében valósult meg, Ezek alapján megállapítható, hogy jelentősen csökkent a csapágyterhelés, tehát érdemes elvégezni az ellensúlytervezést. Figyelembevéve az ipari környezetben történő megvalósítás korlátait csak a statikus kiegyensúlyozás megvalósítását tüztük ki célul, amely igazoltan magában is hatékony. Fel kell hívni a figyelmet, hogy a forgattyúcsap megmunkálhatóságának biztosítása céljából megkonstruált készülékelemek így a forgácsleválasztáskor maguk is okoznak kiegyensúlyozatlanságot, amelyet a munkadarab forgácsolóerők hatására bekövetkező alakváltozása is alakít.

\section{Köszönetnyilvánítás}

A cikkben ismertetett kutató munka az EFOP-3.6.1-16-2016-00011 jelü „Fiatalodó és Megújuló Egyetem - Innovatív Tudásváros - a Miskolci Egyetem intelligens szakosodást szolgáló intézményi fejlesztése" projekt részeként - a Széchenyi 2020 keretében - az Európai Unió támogatásával, az Európai Szociális Alap társfinanszírozásával valósul meg.

\section{Irodalom}

[1] Bálint, L.: A forgácsoló megmunkálás tervezése, Műszaki könyvkiadó, Budapest, 1967.

[2] Mechanikai Tanszék Munkaközössége: Dinamika V., Müszaki könyvkiadó, Budapest, 1981.

[3] Németh, T.: Gépipari szerelés, Müszaki Könyvkiadó, Budapest, 1981.

[4] Király, B.: Dinamika, Miskolci Egyetemi Kiadó, Miskolc, 2006.

[5] Beer, F., Johnston Jr., E. R., Cornwell, P. J., Self, B. P.: Vector Mechanics for Engineers: Dynamics, 12th Edition, McGraw-Hill Education, New York, 2019.

[6] DIN 6885-1:1968: Mitnehmerverbindungen ohne Anzug; Paßfedern, Nuten, hohe Form, német nemzeti szabvány

[7] DIN 1445:1977: Bolzen mit Kopf und Gewindezapfen, német nemzeti szabvány

[8] ISO 7089:2000: Plain washers Form A, nemzetközi szabvány

[9] Gazdag P.: Forgattyús tengely gyártástervezése, Diplomamunka, 2020. 